\title{
Early Childhood Education
}

Cyrus Rohani, Doha, Qatar

\begin{abstract}
Education is a continuous and creative process, which primarily fulfils the moral potential of each individual. Its aim is to develop the capacities latent in human nature and to coordinate their expression for the enrichment, progress and transformation of society.
\end{abstract}

Keywords: Early Childhood Education, Moral Education

Every Child Is Potentially The Light Of The World - And At The Same Time, Its Darkness

\section{NATURE OF MAN}

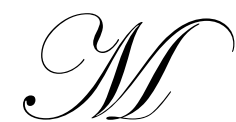

an is the supreme Talisman. Lack of a proper education hath, however, deprive him of that which he doth inherently possess.... The Great Being saith: Regard man as a mine rich in gems of inestimable value. Education can, alone, cause it to reveal its treasures, and enable mankind to benefit therefrom." "

Man is like steel, the essence of which is hidden: through admonition and good counsel and education, that essence can be brought to light. If, however, he be allowed to remain in his original condition, a combination of lust and greed can effectively destroy him.

Man is the end of imperfection and the beginning of perfection. He is the last outpost of darkness, and the beginning of light; that is why it has been said that the condition of man is the end of the night and the beginning of day, meaning that he is the sum of all the degrees of imperfection, while at the same time being capable of perfection. And perfection can only be brought about by good education.

\section{WHEN DOES LEARNING START?}

Learning starts from the time of conception. That is why I believe that the mother is the first educator of her child, and it is essential that priority is given to the education of women. Consequently, it is also vital that the mother's emotional state, her behavior, attitudes, beliefs, working environment as well as her profession particularly during the period of pregnancy need to be watched and controlled.

Scientists at the Fetal Behaviour Research Centre have been doing a lot of research in this area with the aim of producing what they refer to as a "super baby":

\section{Fetal perception}

"The fetus is able to respond to stimulation in all of the main senses, sound, taste or smell, touch and vision. Moreover, rather than being shielded from all these stimuli, the womb environment of the fetus is filled with them. Sounds from the external world, such as the mother's voice, music from the radio pass through the abdomen to reach the fetus's ear. The smells and flavors of the food the mother eats will pass into the amniotic fluid. The mother's diet will stimulate the fetus's taste buds and nose. If the mother eats garlic this passes to the amniotic fluid and when the fetus swallows this fluid it will taste the garlic. The umbilical cord, the walls of the womb, the fetus itself, or a twin if present will all provide tactile (touch) stimuli for the fetus." ${ }^{2}$

\footnotetext{
${ }^{1}$ Gleanings, BPT, page: 346
}

${ }^{2}$ http://www.psych.qub.ac.uk 


\section{Fetal learning}

"Of all the abilities of the fetus, learning has attracted considerable attention for its 'adult like' qualities. In 1988 we found that babies whose mothers had watched the TV programme 'Neighbours' whilst pregnant preferred this tune after birth, even though they had only heard the tune before birth. This clearly showed that the human fetus is capable of learning sounds." 3

\section{Maternal behaviour}

"The fetus does not develop in isolation but is affected by its mother's activities. Maternal behaviors such as smoking and drinking have been shown to exert an effect on the fetus ..." 4

"The mother's emotional state may play in role in the subsequent development and behavior of the fetus. The importance of keeping mothers calm was recognized over 1000 years ago by the Chinese who developed relaxation clinics for pregnant women." 5

\section{EDUCATION}

Education is of three kinds: material, human, and moral.

Material education is concerned with the progress and development of the body. This education is common to both animals and human beings. The best example of this kind of education is body builders who train themselves through diet and exercises in health clubs available in every corner of the world.

Human education signifies civilization and progress - that is to say, government, administration, charitable work, trade, arts and handicrafts, sciences, great inventions and discoveries; all of which are uniquely human activities, distinguishing us from animals. They are facilitated through universities, government offices, and various institutions.

Moral education mean acquiring inner perfection and becoming the centre and reflection of all virtues such as truthfulness, humility, loyalty, honesty, love. For it is in this state that man becomes the manifestation of the words, "Let Us make man in Our image, and after Our likeness." of education is the true and essential education which affects the ethics of life and has a direct effect on the behaviour of each individual. Moral education's curriculum should be developed based on care for and understanding of the human mind and soul.

Ultimately, the purpose of education is primarily to fulfill the moral potential of each individual. In conjunction with this, the fulfillment of the intellectual and practical potential will enable the individual to serve his or her fellow beings and contribute to the general welfare of humankind.

However, for an educational process to be truly successful, it must encourage students to reflect on the conceptual foundations of their education. Education is a continuous and creative process. Its aim is to develop the capacities latent in human nature and to coordinate their expression for the enrichment, progress and transformation of society.

\section{UNIVERSAL EDUCATION}

Ignorance and lack of education result in separation and disunity among mankind. We are living in a global village, therefore we need universal education. We should embark on developing a universal curriculum which

\footnotetext{
${ }^{3}$ http://www.psych.qub.ac.uk

${ }^{4}$ http://www.psych.qub.ac.uk

$5 \longdiv { \text { http://www.psych.qub.ac.uk } }$

6 Bible (Gen. 1:26.)
} 
would promote unity among mankind and be based on love, understanding, acceptance of each other and equality of men and women. If these concepts are realized then the grounds for any kind of warfare will become utterly irrelevant and mankind will finally live in peace. This could create a new type of human resources which would bring about social change rather than human resources which only respond to the labour market.

\section{MORAL EDUCATION}

An educational approach aimed at personal growth and societal transformation must admit that when words and actions are not directed by a moral force, scientific knowledge and technological know-how, they are as likely to cause misery as they may bring about prosperity and happiness. But moral values are not mere constructs of social processes. Rather, they are expressions of inner forces that operate in every human being, and education must concern itself with these forces if it is to tap into the roots of motivation and produce a meaningful and lasting change.

Training in morals and good conduct is far more important than mere intellectual learning. A child that is clean, agreeable, of good character, well-behaved - even though he may be ignorant - is preferable to a child that is rude, unwashed, ill-natured, and yet becoming deeply versed in all the science and arts. The reason for this is that the child, who conducts himself well, even though he may be ignorant, is of benefit to others, while an ill-natured, ill-behaved child is corrupted and harmful to others, despite being learned. If, however, the child can be trained to be both, learned and good, the result is light upon light.

The basis of moral training is attitude, beliefs and values which are all intimately connected and related to each other. They are also directly responsible for the condition of our world. The attitudes and beliefs of an individual will ultimately form the very values which will guide and shape his or her own life and the lives of others. If we examine closely the root cause of all environmental problems, crime, violence, oppression, war, hunger, injustice, poverty, conflict, etc., we find certain negative attitudes - especially those of greed, self-exaltation and self-gratification functioning as a primary motive. These attitudes reflect a core belief that the purpose of life is to gratify the self under all conditions. This belief and these attitudes generate destructive, materialistic and selfish values; values which ultimately translate themselves into the under-development or absence of many noble virtues essential to unity and justice.

The belief in the oneness of humanity, universal peace and unity of mankind is also key to moral behavior. One needs to believe that all humanity deserve our love and respect, etc. Otherwise, it may be possible to have people who only in respect to their tribe, nation, ethnic group, religious affiliation, are consistently moral. If they deem others less than human, they may not practice their virtues in relation to them!

\section{CONCLUSION}

When the spiritual nature of the child is developed well starting from the womb of the mother to the womb of the family, particularly up to the age of five, then the child can emerge into the society strong and healthy, capable of resisting destructive values, attitudes, and habits which will continually bombard him.

We should take utmost care to give children high ideals and goals, so that once they come of age, they will set their hearts on achieving an everlasting honor and excellence of being human.

\section{AUTHOR INFORMATION}

Cyrus Rohani is a freelance management consultant in education and social and economic development projects related to youth empowerment and advancement of women in Asia. His earlier managerial experience was in the field of human resource development in the hydrocarbon industry in Qatar Petroleum, during which his pioneering work on "Opportunities for systematic on the job training" was published by the Organization of Arab Petroleum Exporting Countries (OAPEC) in 1986. He is an economics graduate from the American University of Beirut with an MBA in management from The Sacred Heart University, Connecticut, USA. 
NOTES 